\title{
Cooperatives, Agriculture and Rural Development: Role, Issues and Policy Implications
}

\author{
${ }^{1}$ Dr. Rabi N. Patra, ${ }^{2}$ Mahendra P. Agasty \\ ${ }^{1}$ Reader in Economics Government Science College, Chatrapur, Ganjam-752010 \\ ${ }^{2}$ Asst. Prof. of Economics, Silicon institute of Technology, Bhubaneswar-751024
}

\begin{abstract}
Cooperatives, credit cooperatives in particular, are an integral part of the Indian rural economy. They are having far reaching direct and indirect impacts on agricultural growth and rural development. In the changing scenario characterized by globalisation, structural adjustment programmes, transition from a centrally planned to a market oriented economy, processes of democratisation and decentralisation, agricultural industrialisation and rural out-migration, cooperative are facing new challenge. But they must succeed and have to be resilient to weather the transition. They need to reevaluate and reinvent themselves, adapt to the changing paradigm and reestablish their relevance as effective rural institutions. This paper reviews the evolution of cooperative movement, examines its role and problems, and highlights its potential to adjust to the new perspectives in the context of Odisha, India. It concludes with some policy suggestions reposing great hope on the cooperative sector.
\end{abstract}

Key words: Cooperative credit, agriculture, rural development.

\section{Introduction}

India is essentially rural India. According to Census-2011, 68.84 per cent of total population of the country lives in the county side. They are virtually the cultivator, agricultural laborer, rural artisan, petty retail businessmen and small services provider. Agriculture, rural crafts, cottage industries, small business and services are the mainstay of the rural economy. Performance of the national and sub-national economies draws heavily on rural development and hence on the pace of growth of these activities and on the economic wellbeing of people engaged in them. Provision of credit; input supply; technology dissemination; value addition through diversification favoring high value agriculture, agro-processing and warehousing facilities; and creation of marketing network and infrastructure play a pivotal role in economic transformation in the villages and rural development. The need for institutional arrangements in these core areas is necessitated by the limitations of self-provisioning and heart-breaking exploitation of non-institutional agencies. Credit is the most vital input for economic activities in the rural areas and cooperative credit institutions are the main purveyors, other agencies being commercial banks and regional rural banks (RRBs).

In spite of remarkable GDP growth and substantial diversification in production structure at the macro level in the recent years, the situation in the villages remains largely unchanged. The share of agriculture in GDP has drastically declined from about 50 percent in the 1950s to about 14 per cent during 2012-13 while that in employment reduced at a slow pace from about 75 per cent to 55 per cent during the said period. This means that changes in the production structure moved far ahead of those in the implement structure of the workforce. The ratio of worker productivity in agriculture to non-agriculture is registering a decline despite widespread application of improved farm technology in agriculture. Besides, workers are disinclined to work in agriculture and are migrating to small towns either as daily commuters or as seasonal and/or long period migrants to work in physically less demanding activities. The villages are giving a sad look devoid of prime age population while the urban areas are experiencing over congestion and vertical construction.

In this backdrop an attempt has been made in the paper to focus on the evolution and role of cooperatives in rural development, and assess their problems and future prospects as agents of change, transformation and prosperity. The study covers the host of economic activities in the rural areas with concentration on agriculture, and the variety of rural cooperatives with specific reference to those dispensing agricultural credit. It is based on both secondary data obtained from various published sources and primary data collected from 100 agricultural households sampled out of 220 households of four villages of Iswarpur gram panchayat under Nilgiri block of Balasore district in Odisha, India. A five stage simple random sampling procedure has been adopted to select the sample households with the district, the block, the gram Panchayat, the villages and the households representing the five stages respectively. The primary data relate to the kharif season of the agricultural year 2012-13. Data have been collected by means of a well structured pre tested schedule canvassed in person among the respondents of sample households. Very simple statistical tools have been used to analyse data and interpret the results. 
The paper has been structured in five sections. An overview of the evolution of the cooperative movement in India and the legislative endeavours taken at the national and state levels in that regard have been given in the following section. The working of the cooperative system in Odisha has been discussed in section-3 with focus on cooperative credit and some general observations on the problems and operational issues associated with the cooperative sector. Findings of the primary survey have been presented in section- 4 . Sectioin-5 concludes the paper with some implementable suggestions.

\section{Cooperative Movement in India: An Overview}

A cooperative is a voluntary autonomous association of people designed to meet their common economic, social and cultural needs through a jointly owned and democratically managed organization. Cooperative movement can be defined as a voluntary movement of people to carry out a given economic activity through a democratically controlled enterprise by pooling together their resources with the purpose of securing certain benefits to the members and promoting certain values such as mutual help, self reliance, self management and general good for all.

\subsection{The Seven Driving Principles.}

A cooperative is guided by seven driving principles which are central to their formation, organization and activities. They are the following

\subsubsection{Voluntary and Open Membership.}

A cooperative must justify its existence to the people. Those who feel that they will benefit by it will join and those who feel they will not benefit will stay away. This means that people enjoy entry and exit options.

\section{2..1.2 Democratic Member Control}

A cooperative is managed and controlled democratically by members' representatives elected on the one member one vote principle. Commitment and participation in decision making process are ensured by this principle.

\subsubsection{Member Economic Participation}

Member participation in economic activity is a fundamental principle of cooperation. A cooperative distributes profit arising out of its operations among the members in a judicious and prudent way so that it automatically avoids one or some gaining at the cost of another or some others. So doing it overcomes exploitation of a member by a member.

\subsubsection{Autonomy and Independence}

A cooperative enjoys the right to run its administration and economic activity as it deems fit without undue external interference. It takes decisions on its own and prompt action is ensured.

\subsubsection{Education, Training and Information}

A cooperative endeavors to educate and train its members to improve their economic activity (by adopting new farm technology in the case of agriculture based cooperatives for instance) and provide information to arouse awareness among them and spread the details of cooperatives among the masses. In the process members' positions are strengthened and cooperatives grow into a movement.

\subsubsection{Cooperation among Cooperatives}

A cooperative needs to cooperate and integrate with other cooperatives at local, national and international levels so as to assist each other and improve members' well-being. Cooperatives have the advantage of social capital linkages-horizontal linkages among members and other cooperatives, and vertical linkages among different layers and types of cooperatives and among cooperatives on the one hand and government and institutions on the other. These networks and linkages facilitate creation of larger benefits and equitable sharing thereof.

\subsubsection{Concern for the Community.}

A Cooperative is an integral part of the larger community in which it operates. It needs to dispense its social responsibility for improvement of the community and its neighborhood by partnering in local development initiatives. 


\subsection{The Core Values}

Cooperatives uphold eight core values which may be defined in 5Ss - self help, self reliance, self responsibility, self management and solidarity and 3 Us- user ownership, user control and user benefit. Their members believe in the ethical values democracy, equality, openness, honesty, social responsibility and caring for others. These values make a cooperative a unique organization distinctly different from other organization and associations.

\subsection{Why Cooperatives?}

The cooperative edifice stands on a strong economic foundation and a sound social base. The economic logic behind formation of a cooperative and the spread of cooperative movement lies in the existence of glaring inequalities in the distribution of wealth and income and the need of moderating them through the principles of cooperation. The necessity of liberating people from the tyranny of exploitative practices is the social justification for cooperatives.

\subsection{Evolution}

The cooperative movement has a humble beginning in the world. The first cooperative in recorded history was started as a grassroots level credit institution by a group of wavers and other people in Rochdale, England in the name of Rochdale Equitable Pioneers Society in 1844. The success of this society led to the formation of cooperatives in other parts of Europe and in America, Germany and Japan. In India, the cooperative system owes its origin to Sir Frederick Nicholson who recommended the establishment of credit cooperative on the basis of his enquiry conducted in response to the request of the Governor of the then Madras Presidency in 1892 regarding the possibility of introducing a system of agricultural and other land banks in his territory. The Nicholson Report was implemented and the first credit cooperative was established in the Madras presidency in the year 1894. Later Nicholson was placed in the second commission recommended the cooperative system in line with the Raiffessen model named after Friedrich Raiffessen, a German provincial politician and social reformer who designed the German Cooperative and Riffessen Association around the 1850 s.

In India, as elsewhere in the world, the cooperative system started as cooperative credit societies designed primarily to exonerate the farmers from the cobweb of the usurious village moneylenders. With a great start in 1894, the cooperative system took off, diversified immensely in terms of activities, expanded in geographical and population coverage with a dramatic speed and has grown in to a kind of people's movement over the last 220 years. Nowhere in the world, not even in the UK and Germany where the cooperatives took birth, did the system grow, expand and diversify that rapidly.

\subsection{Legislative Provisioning}

The cooperative movement India has been initiated, nurtured and flourished by active involvement of the government through, among other things, legislative endeavor. The Cooperative Credit Society's act, 1904 marked the foundation of the legislative effort. The cooperative societies act, 1912 is a milestone through which the scope of cooperatives widened to embrace rural, urban, consumer, industrial and marketing cooperatives in the country. The constitutional reforms act, 1919, popularly known as the government of India act, 1919 and Montague Chelmsford Reform Act, 1919 making cooperatives a provincial subject and the Multi-Units Cooperatives Societies (MUCs) Act, 1942 permitting business operation of cooperatives in more than one sate helped in spreading the networks of different kinds of cooperative in both rural and urban areas of the country. The 1942 at provided for incorporation, regulation and winding up of cooperatives whose operations were not confined to one state.

The appointment of the committee on Cooperative law by the government of India in 1956 is an important landmark in the history of cooperative movement in India. In its report submitted in 1956, the committee recommended a model cooperative bill to be made a law with exhaustive rules vesting extensive powers with the state governments to control and regulate the cooperative system. Unfortunately the recommendations were never implemented.

The MUCS Act, 1942 was repealed and the Multi-State Cooperative Societies (MSCS) Act, 1984 was enacted in its place. The MSCS Act. 1984 was later amended in 2002, the year in which the government of India adopted the National cooperative Policy with a view to providing functional autonomy and freedom of enterprise to the cooperatives.

In 1985, the government of India appointed a committee on cooperative Law for Democratization and Professionalization of Management in Cooperatives which submitted its report in 1987 recommending deletion of those legal provisions in State Cooperative Societies (SCS) Acts which were against the democratic character and autonomy of cooperatives. It also suggested incorporation of some new provisions in the SCS Acts which promote democratic process and infuse professionalism in management of cooperatives. Another committee was 
constituted in 1990 under the chairmanship of Choudhary Brahm Prakash to draft a Model State Cooperative societies Bill. The Committee submitted its Report in 1991 suggesting a Model Act with recommendations of minimal state intervention, developing self-reliant and member- governed cooperatives, and politicization and debureaurcratisation of cooperatives. Many states had acted upon the Model act, 1991.

The latest of the legislative endeavours in respect of the cooperatives has been the $97^{\text {th }}$ constitutional amendment, 2011. It stipulates that the citizens shall have the right under article 19(1) to form cooperative societies which means that formation cooperative societies has been made a fundamental right. A new Article 43(B) has been incorporated in the constitution with the provision that the state shall endeavor to promote voluntary formation, autonomous functioning, democratic control and professional management of cooperatives.

\subsection{Committees and Commissions on Cooperation}

Government of India, the Planning commission, the Reserve Bank of India and different ministries of the government have appointed different committees and commissions and sought their recommendations from time to time for strengthening the cooperative system, improving their performance and financial health, and increasing the flow of cooperative credit to the rural sector. These include the Maclagan committee on Cooperation (1915), Royal Commission on Agriculture (1928), Gadgil Committee (1944), Cooperative Planning Committee (1951), Central Committee on Cooperatives (1953), Committee on Cooperative law (1956), Committee on Cooperation (1965), Santhanam Committee (1969), National Commission on Agriculture (1971, 1976), Special Study Group (1971), RG Sariya Committee (1972), working group on cooperation for the Fifth Five year plan (1973), Hazari Committee (1975), CRAFICARD (1981), Committee on Cooperative law (1985), Committee on Democratization and Professionalization of Cooperative Management (1987), Agricultural Credit Review Committee (1989), Expert Committee on Model Cooperative Act (2000), Expert Committee on Rural Credit (2000), Committee on Revitalization Support to Cooperative Credit Structure (2002), Advisory Committee on Flow of Credit to Agriculture and other related activities from the Banking System (2004), Task Force on the Revival of Cooperative Credit Institutions (2004) and High Powered Committee on Cooperatives (2005). All of them have made valuable recommendations in their reports some of which have been implemented and some gathering dust in the stores.

The government has also created some national level institutions for financial, technical, advisory and training support to the cooperative system. These are the Agricultural Refinance Corporation (1962), the National Cooperative Development Board (1964), Vaikunth Mehta National Institute of Cooperative Management (1994) and the NABARD (1981).

\subsection{Organizational Structure}

Organizationally, the rural cooperative credit system has a unique structure with some specializing in short-term credit and some others in long-term credit. In the field of short - term and medium-term rural credit, the cooperatives have a three-tier structure with Primary Agricultural Credit Societies (PACAs) at the base, District Central Cooperative Banks (DCCBs) at the middle level and State Cooperative banks (SSBs) at the apex. The PACs are affiliated to DCCBs and the latter to SCBs with the upper tier functioning as a balancing institution of funds for the lower tier. In the sphere of long-term credit, the cooperatives have a two-tier set up with Primary Cooperative Agriculture and Rural Development Banks (PCARDBs) at the base and State Cooperative Agriculture and Rural Development Banks (SCARDBAs) at the apex level. The organizational structure of the rural cooperative credit system, (RCCs)'s shown in the following diagram.

\section{Organizational structure of RCCS in India}

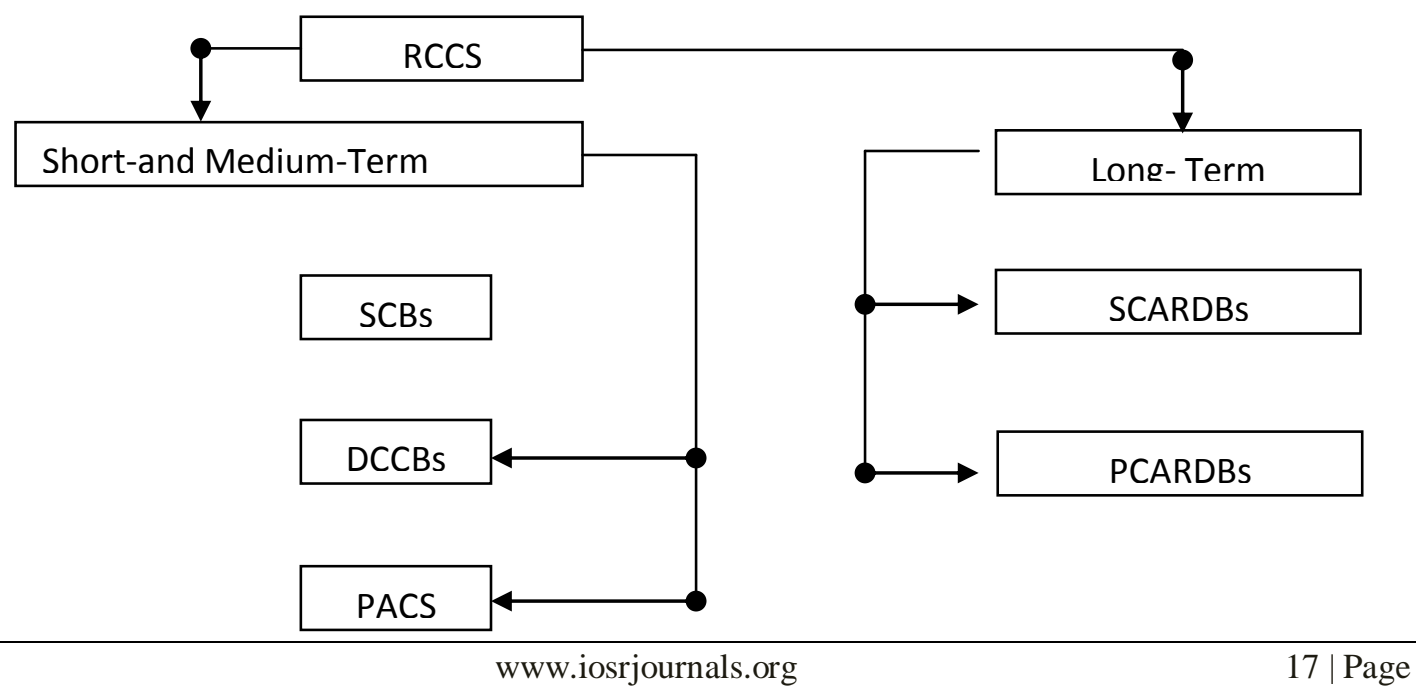




\subsection{Four Phase of Cooperative Credit Movement}

It has become fashionable to analyse the progression of cooperative credit movement in India in four phases. The first phase stretched the period 1900-1930 and it marked the institutionalization of the cooperative system with the passing of the cooperative societies act, 1904, making cooperatives a provincial/state subject mandated by the government of India act, 1919; and active government initiatives and its financial and management support for promoting the credit cooperatives. The second phase 1930-1950- witnessed the establishment of the Reserve Bank of India in 1934 and its key role in strengthening the cooperative rural credit system. The period also showed the signs of growing sickness among the credit cooperatives with frozen assets and heavy overdues. The third phase- 1950-1990- began with introduction of economic planning for faster and equitable economic growth with cooperatives as active agents of change in realizing the national objectives in the arena of rural and agricultural sector. A number committees, working groups, expert groups and national level institutions (such as NABARD) was set up to intensify and widens the activities and promotes the development of the cooperative system. State participation in equity capital, and increasing government patronage for reorganizing the system without addressing the genuine problems led to further erosion in government patronage for reorganizing the system without addressing the genuine problems led to further erosion in governance, management and portfolio quality of the cooperatives. The fourth phase-1990 and after began with nationwide economic reforms with focus on countering the adverse effects of intrusive state patronage, destructive politicization and devastating portfolio management within the cooperative system. Serious impairment of financial health and poor management and governance has been viewed with concern for resurrection of the system.

\subsection{Performance of Rural Cooperative Credit Institutions}

Although the first credit society was established in India in 1984 and cooperatives were institutionalized in 1904, their growth remained modest till the early 1950s. The publication of the AIRCSC report in 1954 and the subsequent acceptance and implementation of the recommendations contained therein by the government marked the watershed in the history of cooperative movement in India. It ushered the era of active state partnership in equity, governance and management in the development of cooperative institutions. The summary remark of the Committee "cooperation has failed but it must succeed" became the buzz word in academic and policy making circles in later years and provided a boost spreading the cooperative gospel among the masses and spearheading the movement in terms of establishing cooperative credit institutions in all nook and corners thereby making them the dominant sources of rural credit in the country. But over the years their position has significantly declined and they now have a markedly smaller role. Tables- 1 and 2 depict the spurts and bursts in the role of cooperatives in the Indian rural credit market.

Table-1

Relative share of different sources in the borrowing of Cultivator Households in India

\begin{tabular}{|c|c|c|c|c|c|c|c|}
\hline & Sources $\downarrow$ & 1951 & 1961 & 1971 & 1981 & 1991 & 2002 \\
\hline & 1 & 2 & 3 & 4 & 5 & 6 & 7 \\
\hline & $\begin{array}{c}\text { Non-Institutional } \\
\text { of which }\end{array}$ & 92.7 & 81.3 & 68.3 & 36.8 & 30.6 & 38.9 \\
\hline & Money- Lenders & 69.7 & 49.2 & 36.1 & 16.1 & 17.5 & 26.8 \\
\hline & $\begin{array}{l}\text { Institutional } \\
\text { of which }\end{array}$ & 7.3 & 18.7 & 31.7 & 63.2 & 66.3 & 61.1 \\
\hline & Cooperatives & 3.3 & 2.6 & 22.6 & 29.8 & 23.6 & 30.2 \\
\hline & Commercial Banks & 0.9 & 0.6 & 2.4 & 28.8 & 35.2 & 26.3 \\
\hline & Unspecified & - & - & - & - & 3.1 & - \\
\hline Source: (1) & Reserve Bank of India: & & & & & & \\
\hline & $\begin{array}{l}\text { (i) } \\
\text { (ii) } \\
\text { (iii) }\end{array}$ & $\begin{array}{l}\text { All India } \\
\text { ii) All In } \\
\text { (iii) NSS }\end{array}$ & $\begin{array}{l}\text { Credit } \\
\text { ral De }\end{array}$ & $\begin{array}{l}\text { y Com } \\
\text { Inves } \\
\text { nd In }\end{array}$ & $\begin{array}{l}\text { 1954, } \\
\text { urvey, } \\
\text { t Surve }\end{array}$ & & \\
\hline
\end{tabular}

(2) NSSO: All India Debt and Investment Survey 2002

Table-2

Shares of Institutional Agencies in Agricultural Credit in India (Per Cent)

\begin{tabular}{|l|l|l|l|l|l|l|l|l|}
\hline Year $\rightarrow$ & $1970-71$ & $1980-81$ & $1990-91$ & $1993-94$ & $1996-97$ & $2000-01$ & $2005-06$ & $2008-09$ \\
\hline 1 & & & & & & & & \\
\hline \multicolumn{1}{|c|}{2} & 3 & 4 & 5 & 6 & 7 & 8 & 9 \\
\hline Cooperatives & 93.22 & 58.90 & 49.03 & 61.34 & 45.22 & 39.28 & 21.83 & 12.82 \\
\hline Commercial Banks & 6.78 & 36.66 & 47.56 & 32.74 & 49.71 & 52.72 & 69.52 & 77.89 \\
\hline Regional Rural Bank & 0 & 4.44 & 3.41 & 5.92 & 6.38 & 8.00 & 8.43 & 9.29 \\
\hline Others & 0 & 0 & 0 & 0 & 1 & 0 & 0.21 \\
\hline Total & 100.00 & 100.00 & 100.00 & 100.00 & 100.00 & 100.00 & 100.00 & 100.00 \\
\hline
\end{tabular}


Up to the 1970, non-institutional sources, moneylenders in particular, supplied all the credit availed by the agriculturists and credit flow from the institutional sources were small. By the end of the 1970s the situation changed significantly with institutional sources accounting for 63.2 per cent and 66.3 per cent of the total borrowings of cultivator households in 1981 and 1991 respectively. However, some reversal in the share of institutional agencies accounted for a 61.1 per cent share which is lower than 66.3 per cent share in 1991. This may be attributed to the broader economic reform measures and financial sector reforms implemented in the economy since 1991 and the procedural rigidities inherent in the institutional sources of credit.

Within the institutional sources, cooperatives are the oldest and they were the dominant sources of farm credit accounting for 93.22 per cent of total institutional credit taken by the cultivator households in 1970-71. By 1980-81, their share fell to 58.90 but they still remained the dominant purveyors of agricultural credit. Their share fell further to 49.03 per cent in 1990-91 and the space vacated by them was taken over by commercial banks and regional rural banks. The share of commercial banks increased from 6.78 per cent in 1970-71 to 3666 per cent in 1980-81 and further to 47.56 per cent in 1990-91. The share of RRBs which were established only in 1975 fell from 4.44 per cent in 1980-81 to 3.4 per cent in 1990-91.

This trend reversed in 1993-94 when the share of cooperatives increased to 61.34 per cent and that of commercial banks fell to 32.74 per cent. Between 1990-91 and 1993-94, the share of RRBs increased to 5.92 percent. But the decline in the share of commercial banks in agricultural credit was short lived and it increased consistently since then outpacing the share of cooperatives. The share of RRBs has been on the increase too. In 2008-09, cooperatives had a meager share of just 12.82 per cent, commercial banks had 77.89 per cent and RRBs had 9.29 per cent stake in farm credit. The policy initiatives for expansion of rural branch network and increasing for amalgamation and merger of RRBs, and focus on financial discipline in the case of cooperatives may be reasons for the changed in the relative share of institutional agencies in agricultural credit in India.

\section{The Cooperative Movement in Odisha}

The establishment of the Cuttack cooperative Store in 1889 under the stewardship of Utkal Gourav Madhu Sudan Das marked the dawn of cooperative movement in Odisha . In 1903, three cooperative credit societies were set up in Banki of Cuttack district which later became the Banki Central Cooperative Banks in 1910. Thus viewed Cuttack town and Banki laid the foundation for a robust cooperative movement in the state.

\subsection{Legal Provisions for Cooperatives in Odisha}

The cooperative movement in Odisha was originally governed by the Bihar-Orissa Cooperative Societies act, 1935. After gaining the separate statehood in 1936, Orissa enacted its first cooperative legislation named the Orissa Cooperative Land Mortgage Bank act, 1938 to meet the long term credit needs of farmers through cooperatives. Later on, the Orissa Cooperative Societies act, 1951 was enacted with a view to regulating the cooperatives in the state. The 1951 act was repealed by the Orissa Cooperative Societies act, 1962. The 1962 act is still in vogue with amendments made to some of the original provisions at different points of time to meet the changing circumstances.

In tune with changing national policies, Orissa too entered into an era of economic reforms beginning in 1991. It was the first state to adopt most of the recommendations of the committee on Model Cooperative Act,1991 (Choudhary Brahm Perkash Commiittee) concerning the model cooperative law. In addition, the government enacted the Orissa Self Help Cooperatives act, 2001 to restore the true spirit of cooperation in the cooperative system. In line with the Vaidyanathan Committee recommendations (2004) the govt.of Orissa amended some of the provisions of the 1962 Act and the corresponding rules have been given effect to since 2010. The 1962 Act was further amended on 24 September, 2011 to strengthen the cooperatives and efforts have been initiated to introduce changes therein in tune with the $97^{\text {th }}$ constitutional amendment Act, 2011.

\subsection{A Brief Profile of Cooperatives in Odisha}

Over the years the geographical coverage of cooperatives has increased, their management has expanded and their scope has enlarged beyond credit and thrift

\subsubsection{Management}

The geographical organization of cooperatives comprises 58 circles functioning under 19 divisions covering all the 30 districts of the state. The Registrar of Cooperative Societies (RCS) is the head of the cooperative organization under whose stewardship the system is working and managed. The other officials include the additional RCS, the joint Registrars, Deputy registrars, Assistant registrars, the Administrative officer, the Accounts officer, the Law officer and other staff. The Board of Management consisting of the Director, Secretary, elected representatives looks after the management at the field level.

\subsubsection{Scope of Cooperatives}

Cooperatives were originally visualied as credit and finance institutions designed to liberate the credit starved cultivator households from the clutches of the private exploitative moneylenders. With the passage of time and changing circumstances their scope has been widened to include other activities such as marketing, 
consumer sector, housing and training and education. The marketing cooperatives operate through 47 regional cooperative marketing societies, 15 cold storages and a number of godowns with the Orissa State Cooperative marketing Federation at the apex. The consumer sector is functioning through 20 wholesale consumer cooperative stores and 314 primary consumer's stores with the Orissa consumers' Cooperative Federation at the apex. The housing sector is working through the Orissa Cooperative Housing Corporation at the apex and 103 primary house building cooperatives at the base. Operationally, the cooperative sector has stretched a lot to cover most of the economic activities in the rural and urban areas and they include handloom cooperatives, fisherman cooperatives, milk and dairy cooperatives with OMFED, industrial cooperatives, stone carving, image making and utensil preparing societies, oilseeds cooperatives and so on. The training and education segment has the Madhu Sudan Institute of Cooperative Management as the state level organization for imparting education and training on routine matters and management to officers and field staff of cooperatives and sharing of information among the members of societies.

At present 7543 cooperative societies are functioning in the state of which 4432 are working under the administrative control of Registrar of cooperative societies. The rest are operating under OMFED, Director of Industries, Director of Textiles, Director of Fisheries, and Director of Animal Husbandry and Veterinary services.

\subsection{Status of Credit Cooperatives in Odisha}

The cooperative credit system has developed in Odisha along the all India pattern. It has a simple structure for the urban areas with 14 urban cooperative banks dispensing credit to the urban clientele through their numerous branches. For the rural areas, the system has a complex structure with distinct arrangements for long-term and short-and medium-term credit. The Orissa State Cooperative Agriculture and Rural Development Bank (OSCARDB) caters to the long-term credit needs of the rural households through its 46 branches spread over different parts of the state. In 2004-5 they provided Rs. 7.54 crore as loans but since then no loan has been given as the OSCARDB have defaulted to the NABARD.

In the field of short-and medium-term credit, the cooperatives have a three-tier structure with PACS at the base- village level,the DCCBs at the intermediate level and the State Cooperative Bank (OSCB) at the apex. In tune with the recommendations of the Special Study Group, 1971, the government of Orissa set up Large Sized Multi-Purpose Cooperative Societies (LAMPS) in tribal areas. They constitute the bottom structure in the tribal areas as the PACS in the non-tribal areas. The LAMPs provide all types of credit and technical guidance under one roof and arrangements for marketing of agricultural and tribal based products.

In the dispensation of short-and medium-term credit in the rural areas, the cooperatives are doing a commendable job. They have brought 51.16 lakh of the 55 lakh cultivator households in the state under their fold as at the end of June, 2012, the coverage being 93 per cent. Established in 1948 and operating through its 15 branches with 38742 members, the OSCB is one of the most successful SCBs in the country. It has been earring profit consistently since inception. The 17 DCCBs operating through their 333 branches with 154963 members covering all the 314 blocks of the state are affiliated to and assisted financially and supervised by the OSCB. As on 31 March, 2011, the state has 2452 PCs with 4454280 members. They are affiliated to DCCBs and the OSCB and are financially assisted and supervised by them.

Following the directives of government of India the state has introduced the Kissan Credit Card Scheme (KCCS) in 1998-99 to provide hassle-free, adequate and timely crop loan to farmers. by the end of June, 201251.64 lakh farmer members have been issued the KCCs of which cooperatives account for 40.04 lakh or 77.54 per cent and the balance 11.60 lakh or 22.46 per cent have been covered by commercial banks and RRBs. In 2004-05, the government of India announced a scheme for doubling dispensation of farm credit in a span of three years by 2006-07. The cooperative sector in Odisha has successfully implemented the scheme. The flow of short-term credit cooperatives has increased from Rs 742.49 crore in 2003-04 to Rs 1550.17 crore in 20006-07 and further to Rs. 3396.39 crore in 2010-11.

In the sphere of short-term credit, cooperatives have achieved major strides in credit-deposit ratio in the state vis-à-vis commercial banks. The ratios are estimated at 97.67 for cooperatives and 62.85 for commercial banks for the year 2009-10 and have increased to 114.8 for cooperatives as against 70.25 for commercial banks for the year 2011-12. This means that cooperatives are injecting more credit to than they are suctioning out in deposits from the rural areas but the reverse is true of the commercial banks. Credit provisioning to share croppers for agricultural operations has been a novel feature of the cooperative system in Odisha. An innovative initiative has been taken to promote credit linkage on SHG model to tenant farmers groups and joint liability groups under this programme.

A comprehensive crop insurance scheme was introduced in the state in 1985-86 and the national agricultural Insurance Scheme (NAIS) is being implemented since 1999-2000 Rabi season. The agricultural insurance Company of India Limited is the implementing agency. Under this scheme, Crop insurance is compulsory for the loanee farmers and it is optional for the non-loanees. A new insurance scheme known as the Wealthier Based Crop Insurance scheme (WBCIS) was introduced in Orissa in 2008. Since 2009 the scheme 
covers 19 blocks of Baragarh, Bolangir and Nuapada districts which are outside the purview of the NAIS. In these Blocks the unit of insurance is the Block and indemnity is settled on the basis of weather parameters like excess/deficit in rainfall.

Odisha is prone to distress sale of paddy and farmers are the obvious worst sufferers. Initiative of shortterm cooperative credit in market intervention and procurement of paddy through PACS/LAMPS as commission agents of Orissa State Civil Supplies Corporation has helped farmers to get remunerative prices (MSP Plus) and the cooperative credit system itself for improved loan recovery. Grant-in-Aid has been provided to the PACs/ LAMPS for repair and renovation of godowns to facilitate paddy procurements.

\subsection{Performance of PACs in Odisha}

PACS constitute the base legal cooperative credit institutions which deal directly with the cultivator households in the rural areas. They provide primarily short-term loans to the famers. Any reform measure for restructuring and revitalizing the cooperative sector has PACS as the focus of attention. PACS which were originally visualized as the predominant credit providers had to bear the brunt of restructuring, liquidation and amalgamation following the changing norms of viability and sustainability suggested by committees, commissions, expert groups, task forces etc. from time to time. Hence, the number of PACS in the state, as elsewhere in the country and at the national level, has shown significant changes over time. Accordingly, the membership, working capital, deposits, loans and advances, recoveries and overduse etc. of the PACS have shown wide fluctuations over the year. The performance of PACS at the state level can be examined and analysed by looking at different parameters selected for the purpose relevant data are presented inTable-3

Table -3 : Performance of PACS in and India, 2010-11

\begin{tabular}{|c|c|c|c|}
\hline SI No & Indicators & & India \\
\hline \multirow[t]{4}{*}{1} & $\begin{array}{l}\text { No. of PACS } \\
\text { No. of viable PACS }\end{array}$ & $1810(78.82)$ & $65985(70.64)$ \\
\hline & No. of Potentially Viable PACs & $512(20.88)$ & $21598(23.12)$ \\
\hline & NO. Of Dormant, Defunct \& Other PACS & $130(5.30)$ & $5830(6.243)$ \\
\hline & Total & $2452(100.00)$ & $93413(100.00)$ \\
\hline 2 & Percentage of Villages Covered & 95.54 & 93.67 \\
\hline \multirow[t]{7}{*}{3} & Membership (in thousands) & & \\
\hline & Scheduled Castes & $678.00(15.22)$ & $15384.51(12.69)$ \\
\hline & Scheduled Tribes & $999.44(22.44)$ & $9806.92(8.09)$ \\
\hline & Small Farmers & $2053.00(46.09)$ & $39070.16(32.23)$ \\
\hline & Rural Artisans & $156.39(3.51)$ & $5390.03(4.45)$ \\
\hline & Marginal Farmers and Others & $567.45(12.74)$ & $51573.26(42.54)$ \\
\hline & All Categories & $4454.28(100.00)$ & $121224.88(100.00)$ \\
\hline \multirow[t]{7}{*}{4} & \multicolumn{3}{|l|}{ Borrowing Membership (in thousands) } \\
\hline & Scheduled Castes & $220(13.27)$ & $5663.24(10.81)$ \\
\hline & Scheduled Tribes & $421(25.39)$ & $3754.42(7.17)$ \\
\hline & Small Farmers & $762(45.96)$ & $15494.44(29.57)$ \\
\hline & Rural Artisans & $81(4.88)$ & $2879.00(5.50)$ \\
\hline & Marginal Farmers and Others & $174(10.50)$ & $24596.52(46.95)$ \\
\hline & All Categories & $1658(100.00)$ & $52387.59(100.00)$ \\
\hline \multirow[t]{5}{*}{5} & \multicolumn{3}{|l|}{ Short - Term Loans Issued (Rs. Lakh) } \\
\hline & Scheduled Castes Borrowers & $19969(8.48)$ & $476034.68(6.31)$ \\
\hline & Scheduled Tribes Borrowers & $36745(15.60)$ & $246789.31(3.27)$ \\
\hline & Other Borrowers & $178794(75.92)$ & $6819858.06(90.42)$ \\
\hline & All Borrowers & $235508(100.00)$ & $754262.05(100.00)$ \\
\hline \multirow[t]{5}{*}{6} & \multicolumn{3}{|l|}{ Medium- Term Loans Issued (Rs. Lakh) } \\
\hline & Scheduled Castes Borrowers & $1545.71(9.39)$ & $113505.51(7.15)$ \\
\hline & Scheluled Tribes Borrowers & $2579.64(15.66)$ & $42201.34(2.66)$ \\
\hline & Other Borrowers & $12343.02(74.95)$ & $1431993(90.19)$ \\
\hline & All Borrowers & $16468.37(100.00)$ & $1587700.21(100.00)$ \\
\hline \multirow[t]{5}{*}{7} & \multicolumn{3}{|l|}{ Percentage of Overdues to Demand-short-Term } \\
\hline & Scheduled Castes & 43.68 & 33.22 \\
\hline & Scheduled Tribes & 22.78 & 34.89 \\
\hline & Others & 31.40 & 22.77 \\
\hline & All Categories & 31.45 & 23.80 \\
\hline \multirow[t]{5}{*}{8} & \multicolumn{3}{|l|}{ Percentage of Overdues to Demand-Medium-Term } \\
\hline & Scheduled Castes & 67.09 & 46.19 \\
\hline & Scheduled Tribes & 42.05 & 52.79 \\
\hline & Others & 35.38 & 31.99 \\
\hline & All Categories & 40.46 & 33.85 \\
\hline 9 & Percentage of Overdues to Demand - Agriculture & 32.78 & 37.92 \\
\hline 10 & $\begin{array}{l}\text { Perdcentage of Overdues to Demand - Non- } \\
\text { Agriculture }\end{array}$ & 46.10 & 16.45 \\
\hline
\end{tabular}


The table points to poor financial health of the PACS in both Odisha and India. Viable PACS account for 73.82 per cent. Potentially viable PACS constitute 20.88 per cent and non-viable PACS comprise 5.30 per cent of all PACS in the state. The respective figures are 70.64 per cent. 23.12 per cent and 6.24 per cent for the country as a whole. A good thing is that PACS cover 95.54 per cent of villages in and 93.67 per cent of villages at the all India level.

In the membership of PACS in Odisha small famers dominate (46.09 percent). They are followed by STs (22.44 per cent), SCs (15.22 per cent), marginal farmers and other (12.74 per cent) and rural artisans (3.5 per cent) At the national level marginal farmers and others are the predominant category (42.54 per cent), STs (8.09 per cent) and rural artisans ( 4.45 per cent) come next in that order. This suggests that PACs are for the asset poor and socio-economically weaker people.

Borrowing membership of PACS exhibit the same pattern as the membership of PACS at the state and national levels. A disheartening fact about the performance of PACS in and at the all India level is the low proportion of borrowers to total members for all the member categories and at the aggregate level. The overall proportion works out to 37.22 per cent for Odisha and 43.22 per cent for India. This point to the unwillingness of cultivator households to borrow from PACS despite incentives of interest rebate allowed to regular repayers.

Another unpleasant thing about the PACS is that both in the case of short-term and medium- term loans issued by them, non-SC and non-ST borrowers have a lion's share. They account for 75.92 per cent of shortterm loans and 74.95 per cent of medium term loans in Odisha but more than 90 per cent of both categories of loans at the all India level. Between the SC s and STs, the latter have a higher share at the state level but a lower share at the national level in respect of both short-term and long-term loans. It seems that equity issues are not adequately addressed at the PACS level.

The PACS have a bad image when it comes to recovery performance and overdue. In the case of shortterm loans, overdue constitute 31.45 per cent of demand in Odisha as against 23.80 per cent in India. In respect of Medium-term loans, the respective figures are 40.46 per cent for Odisha and 33.85 per cent for India this suggests what recovery performance of PACs is better at the all India level compared to Odisha. At the national level and for both short-term and medium-term loans, the percentages of overdues are the highest for STs followed by SCs and other. In the case of Odisha, the overdues percentage is the highest for SCs in respect of both short-and medium-term loans between STs and others, the percentage is higher for the former in respect of medium-term loans but the reverse is true in respect of short-term loans. This shows that the socially weak can be quite strong when it comes to loan delinquency.

Activity-wise overdues scenario presents a highly disquieting picture. The percentage of overdues to demand are quite high for agriculture loans i.e. 32.78 percent for and 37.92 percent for India. The frequent debtwaiver programmes announced by the government can be a prominent reason for high agricultural overdues. Between agricultural and non-agricultural activities the percentage of overdues are higher in respect of the former at the national level but so in respect of the latter for Odisha.

\section{Empirical Findings}

With a view to examining the role and relevance of PACS in financing agriculture we have conducted a village level survey by canvasing a pre-tested schedule among 100 randomly selected respondents of cultivator borrower households. The results of the investigation are revealing.

\subsection{Occupational structure of Male workers}

Agriculture is a labour-intensive activity. A sizeable proportion of the rural workforce is still engaged in agriculture. Relevant data in this regard are given in Table-4.

Table-4: Occupational Structure of Male Workers

\begin{tabular}{|c|l|c|}
\hline Sl. No. & \multicolumn{1}{|c|}{ Occupation } & Number of Workers \\
\hline $\mathbf{1}$ & \multicolumn{1}{|c|}{$\mathbf{2}$} & $\mathbf{3}$ \\
\hline \multirow{2}{*}{$\mathbf{2}$} & $\begin{array}{l}\text { Workers in Agriculture } \\
\text { Age: 15-35 years }\end{array}$ & $27(9.28)$ \\
\cline { 2 - 3 } & Age: 36-63 years & $134(46.05)$ \\
\cline { 2 - 3 } & All Age & $161(55.33)$ \\
\hline \multirow{2}{*}{$\mathbf{3}$} & $\begin{array}{l}\text { Workers in Non-Agricultural Activities } \\
\text { In Rural Areas }\end{array}$ & $58(19.93)$ \\
\cline { 2 - 3 } & As Migrants in Urban Areas & $72(24.74)$ \\
\cline { 2 - 3 } & All Areas & $130(44.67)$ \\
\hline \multirow{3}{*}{} & All Workers & $291(100.00)$ \\
\hline
\end{tabular}

Source: Field survey

Note: figures in parentheses indicate percentages 
The table indicates agriculture- centric occupational pattern of the workforce. The share of agricultural workers in total male workers is estimated at 55.33 per cent. Within the male agricultural workforce category, those in the prime age group (15-35 years) account for only 9.28 per cent and the balance 46.05 per cent constitute aged workers (36-63 years). This point at growing evidence of ageing male workforce in agriculture and marginal involvement of the young workers in agricultural activities. It also supports the findings of other researchers regarding withdrawal of workers from agriculture.

\subsection{Sources and costs of Credit.}

Over the years the government has put in enormous efforts emphasizing increasing flow of credit to agriculture, required policy attention towards growth of agricultural credit and appropriate institutional reforms. Cooperatives and PACS in particular have been the focus of all efforts and policy intervention for restructuring agricultural credit. In consequence the formal source of credit have gained market share from the informal source. We have made attempts to find out the relative share of different source in the borrowings of cultivator households and related information in our survey. Table-5 contains the desired data.

\section{Table:5. Relative Shares of Sources in Borrowings of Cultivator Households and Costs}

\begin{tabular}{|c|c|c|c|c|c|c|}
\hline $\begin{array}{c}\text { Sl. } \\
\text { No }\end{array}$ & Sources of Credit & $\begin{array}{c}\text { Percenta } \\
\text { ge Share }\end{array}$ & $\begin{array}{c}\text { Time } \\
\text { Gap }\end{array}$ & $\begin{array}{c}\text { Transacti } \\
\text { on Costs }\end{array}$ & $\begin{array}{c}\text { Rate of } \\
\text { Interest }\end{array}$ & Overdues \\
\hline 1 & 2 & 3 & 4 & 5 & 6 & 7 \\
\hline 1 & Moneylenders & 11.9 & 3 & 21 & 36 & Nil \\
\hline 2 & Women SHGs & 18.3 & 3 & 21 & 36 & Nil \\
\hline 3 & Commercial Bank & 6.2 & 36 & 700 & & 19 \\
\hline 4 & Regional Rural bank & 13.1 & 34 & 700 & & 21 \\
\hline 5 & PACS & 50.5 & 30 & 270 & 4 & 31 \\
\hline 6 & All Source & 100.0 & & & & \\
\hline
\end{tabular}

Source : Field Survey

Note: Time gap measured in number of days of gathering the loans; transactions costs include paper and documentation expenses, travel charges and implicit and explicit wage cost. Interest in percentages; and overdues as percentage of demand.

It can be read off the table that the sample farmer households obtained credit from both institutional and non-institutional sources. Professional unregistered moneylenders-cum-petty businessmen and retired defense self-help groups, though registered and supposed to be governed by conditions meant for institutional agencies, are behaving like quasi-non-institutional sources. Both these sources advance hassle - free credit on the basis of promissory notes, do not demand collateral, charge a 3 per cent interest per month and insist on regular interest getting the loans are very small i.e. 3 days and Rs 21 respectively. No overdues are reported, loans are just renewed with monthly payment of interest. The other three institutional agencies are commercial bank, regional rural bank and PACS- one each operating close to the sample villages.

Five important facts have been revealed in the course of data collecting through discussions with officials of lending institutional, respondent and focus groups. The first is that cooperatives are the best suited for purveying agricultural credit. Their share in the average borrowings were 50.5 per cent. They are affordable, the effective interest rate for regular repayers being just 4 per cent per annum. Second the government policy of extending hassle-free credit is observed more in theory than in practice. Smooth credit delivery is thwarted by insistence on collateral (despite provision for extending loans up to Rs 1,00,000 free of collateral), complex lending procedures, inflexible lending rules including cumbersome documentation, longer time gap for getting the loan, high transaction costs and the mistaken accompanied by inadequacy of loan amount forces the borrowers to fall prey to non-intuitional agencies and SHGs.

Third, evidence suggests that some agricultural loans obtained at a lower rate than the market rate of interest because of the interest subvention allowed on crop loans are being diverted to non-contracted issues. This defeats the very purpose of interest subvention policy. The fourth issue which surfaced during the survey relates to improper documentation. Anecdotal evidence indicates that borrowers could manage to secure loans from two institutional sources- RRB and PACs- with the same collateral. This points to laxity in scrutiny of loan application proposals on the part of officials of these agencies. Of course, the commercial bank and RRBs are found to be strict disciplinarians than the PACS in this regard.

Finally, large overdues are common with the institutional policies followed in the recent past are acting as defaulter rewarding incentives confirming their expectation of continual debt-waiving and eroding repayment.

These five problems characterize all the three institutional sources and need to be addressed with caution and commitment. 


\section{Summary And Policy Implications}

In India the cooperatives started a self-help and mutual benefit sharing credit organization, expanded later with government patronage and participation, and over the year, developed into a vast network of public institutions and a people's movement. They have become the life blood and key partners, agents of eternal vigilance, a medium of public awareness, a vibrant civil society organization and have been playing a lead role in the socio-economic development of the Indian rural economy. The 93413 PACS, which constitute the base of the short-term cooperative credit system in rural India, have a reach for wider than all the branches of commercial banks and RRBs taken together. As an organization of the poor, illiterate and unskilled people designed to overcome the constraints of credit, reduce social cleavages and soften economic inequalities, their origins lay in what is now paraphrased as financial inclusion. They are like the modern one stop of malls for non-stop shopping where a farmer can access credit, farm inputs, technical guidance, storage and marketing. Thus viewed they are the potential institutions for transforming small holder agriculture into a viable business enterprise enabling the small ones to enter a world of bigness and acting as vehicles for effective financial inclusion.

For quite a long period the performance of PACS, and for that matter the cooperatives, has been quite dismal. This is reflected in deteriorating asset quality with large NPAS, misgovernance and mismanagement of assets and liabilities, low resource base and high dependence on external funding (recall NABARD refinance and the cooperative credit system would collapse), intrusive state patronage and multiplicity of authority, aggressive politicisation and over-bureaucratisation, deficiencies in loan sanction and lack of post-disbursement follow up, and poor recovery and mounting overdues. The principles of sound finance and prudent credit system are undermined by loan-waivers inducing willful default and the entire cooperative institutional mechanism has remained borrower-driven rather than member-driven.

The expansion of the cooperative movement in India involved active government intervention in the spheres of supervision, auditing, shareholding, management and regulation- a package of conflicting roleswhich undermined professionalism, weak ended the cooperatives and made them moribund. Cooperative credit is grossly inadequate and largely time-consuming for which the informal source still continue to have a strong hold in the counter side. Surprisingly cases of institutional overlapping in credit provisioning are not very rare. In the changing scenario characterized by worldwide economic reforms and increasing marketisation, cooperatives are facing new challenges of competition not only from the private players but also from commercial banking and regional rural banking sectors. They must work hard to meet the existing and emerging challenges with focus on professionalism, efficiency and productivity.

Decades and decades, committees and commissions passed off with recommendations to address the various issues and challenges facing the cooperatives. In most cases the recommendations were either thrown to the dustbins left in the store to accumulate dust implemented without commitment or their implementation gave rise to more problems than they solved. The agenda still remains unaccomplished.

Some of the restructuring measures proved unrealistic and impracticable. For example, the cooperatives are required to adopt prudential norms, asset classification and capital adequacy standards prescribed by Basel-II even knowing fully well that they have not been used to a regular balancing of cash books and ledgers. It is a tall dictat analogous to desiring a two-year old baby to have a taste of chilli sauce on the very first day of introducing him to eating food. Another instance of faulty policy intervention has been frequent capital injection to the cooperative sector when the authorities are well aware of the high credit risks in PACS, lending to the farm sector- the most vulnerable of all activities. Ensuring better risk management and quality governance could have been a better policy to strength them. Thus viewed, policy interventions have allowed the sinking cooperatives to drown further into dormancy and non-viable positions.

Unsurprisingly, the implementation of the Vaidyanathan Committee Revival Package benefited only the financially disciplined PACS. This has two defects. First, when the once-for-all sop expired, the beneficiary PACS had a very painful existence. Second, in places where PACS exited because they did not conform to norms of financial discipline and viability, a branch of a commercial bank or a Gramin bank emerged- a case of a bigger whale eating the small fish.

Taking 1904 as the year of institutionalization of cooperative credit system in India, we have celebrated the centenary of cooperative movement with pomp and vigour and by organizing academic seminars, symposia and conferences in 2004 throughout the country. 2012 has also been observed as the international year of the cooperatives worldwide. It has aptly been confirmed in the academic and policy making for that cooperatives are the most suitable organizations for dispensing credit, providing technical and supervisory support, supplying inputs and essentials, and disseminating production, processing, storage and marketing information in the rural areas. In the fitness of things they are the most effective instruments of rural development. They have a vast institutional tiered network covering almost all villages and can do miracles if they can muster competitive strength, infuse accountability and transparency into their functioning ensure productive loan utilization, improve credit appraisal and risk management practices, insulate them from undue government interference, 
attain political neutrality, develop a personal approach to loan recovery and create necessary awareness among the people.

It is high time to introduce strict and appropriate institutional reforms in the cooperative system. Necessary administrative preparedness must be created at the executive level to initiate and administer instantaneous action against the erring officials, employees and willful defaulters to guarantee staff discipline and promote recovery.

Adequate credit provisioning is no doubt a necessary condition for generation of income and gainful employment for the borrower cultivator households and for rural development but it is not the sufficient condition for ensuring such improvement. Necessary credit counseling and technical guidance must be provided along with the supply of adequate affordable and timely credit. This requires establishing credit counseling centre's and building client capacities for enhancing credit absorptive ability of the borrowers. A shift in emphasis from subsidized credit to supervised credit will prove beneficial both for productive loan utilization, prompt recovery and credit recycling. Secondly, short-term crop loans exhibit better recovery performance than medium term loans because the latter are for a comparatively longer period and the borrower usually relaxes on the plea of an elongated repayment period. Special care needs to be taken to tackle this problem. Third and foremost, the government should refrain itself from announcing populist debt relief sops which have dangerous implications for both end- use and repayment of credit. It has also to be little cautious in participating in the share capital of cooperatives as such participation, by assuring bail out in case of financial difficulty, can prove detrimental to their recovery performance.

The role of the government in withstanding the recent global recession gives a ray of hope pointing clearly at its ability to thwart institutional disasters in the case of cooperatives. What is needed is strong willingness to act. The hole and the yacht need to be repaired before the boat drowns.

\section{References}

[1]. Dwivedi, R.C. (2005): Hundred years of Cooperative Movement in India, Centre for Promoting Cooperatives.

[2]. Government of India (2005): Report of the Task Force on Revival of cooperative Credit Institutions, Ministry of Finance

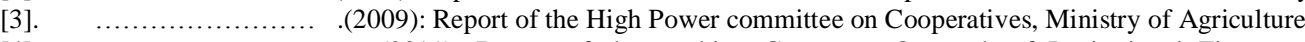

[4]. (2011): Report of the working Group on Outreach of Institutional Finance, Cooperative and Risk Management for the $12^{\text {th }}$ Five Year Plan, Planning Commission in of India

[5]. Mishra, B.S. (2010): Performance of Primary Cooperatives in India: An Empirical Analysis, MPRA paper no.21890 NABARD website

[6]. NAFSCOB (2011): Basic Data on Performance of State Cooperative Banks (April-1, 2009 to March-31, 2010)

(2011): Basic Data on Performance of District Central Cooperative Banks (April-1,2010 to March-31, 2011

(2012): Performance of Primary Agricultural Credit Societies (April-1, 2010 to March-31 2011)

[7]. NSSO (2005): All India Debt and Investment Survey, 2002

[8]. RBI (1954): Report of the All India Rural Credit Survey Committee

[9]. (1965): All India Rural Debt and Investment Survey, 1961-61

[10]. (1977): All India Debt and Investment Survey, 1971-72

[11]. (1987): All India Debt and Investment Survey, 1981-82

[12]. (2000): All India Debt and Investment Survey, 1991-92

[13]. Subbarao, D (2012): Agricultural Credit-Accomplishments and Challenges, RBI bulletin 